\title{
Performa Pertumbuhan dan Kelulushidupan Lobster Air Tawar Capit Merah (Cherax quadraciantus) melalui Formulasi Pemberian Pakan dengan Frekuensi yang Berbeda
}

\section{Growth and Survival Performance of Redclaw (Cherax quadraciantus) through Different Frequencies of Feeding Formulations}

\author{
Partini $^{1}$, Hadra Fi Ahlina ${ }^{2}$ dan Syaiful Ramadhan Harahap ${ }^{3 *}$ \\ ${ }^{1}$ Program Studi Agribisnis, Universitas Islam Indragiri, Indragiri Hilir, Indonesia \\ ${ }^{23}$ Program Studi Budidaya Perairan, Universitas Islam Indragiri, Indragiri Hilir, Indonesia \\ "Koresponden: syaiful.r.harahap@gmail.com
}

\begin{abstract}
Abstrak
Lobster air tawar capit merah Redclaw (Cherax qudricarinatus) merupakan komoditas perikanan air tawar yang sangat potensial untuk dikembangkan sebagai komoditas budidaya. Performa pertumbuhan dan kelulushidupan dapat ditingkatkan dengan meningkatkan frekuensi pemberian pakan. Tujuan penelitian adalah untuk mengetahui frekuensi pemberian pakan yang optimal dalam mendukung pertumbuhan dan kelulushidupan. Perlakuan yang diuji adalah variasi frekuensi pemberian pakan 2 kali sehari, 3 kali sehari, dan 4 kali sehari. Lobster Redclaw yang digunakan memiliki bobot tubuh rata-rata $0,53 \pm 0,11$ gram dengan panjang rata-rata $3,15 \pm 0,02 \mathrm{~cm}$. Pemeliharaan dilakukan selama 90 hari dalam wadah akuarium, dengan padat tebar 20 ekor/wadah. Jenis pakan yang diberikan adalah pelet udang PF 100 ukuran 0,4-0,7 mm dengan proporsi 3\% dari berat biomassa. Hasil penelitian menunjukkan bahwa perbedaan variasi frekuensi pemberian pakan tidak berpengaruh secara signifikan terhadap performa pertumbuhan dan kelulushidupan. Nilai parameter kualitas air pada seluruh wadah selama pemeliharaan masih mendukung pertumbuhan dan kelangsungan hidup lobster air tawar capit merah.
\end{abstract}

Kata kunci: Lobster Air Tawar, Frekuensi Makan, Pertumbuhan, Kelulushidupan

\begin{abstract}
Redclaw (Cherax qudricarinatus) is a potential freshwater species for aquaculture in Indonesia. Growth and survival performance can be improved by increasing the frequency of feeding. The purpose of this study was to determine the optimal frequency of feeding to increase growth and survival performances. The treatments used in this experiment were variations of feeding frequency is 2 times/day, 3 times/day, and 4 times/day. Redclaws used in this experiment has an average body weight of $0.53 \pm 0.11$ grams with an average length of $3.15 \pm 0.02 \mathrm{~cm}$. Maintenance is carried out for 90 days in an aquarium with stocking density of 20 fish/container. The type of feed given is PF 100 shrimp pellets with a size of 0.4-0.7 mm with a proportion of $3 \%$ by weight of biomass. The results showed that differences in feeding frequency did not significantly influence growth and survival rate performance. The water quality parameters in all containers still supports the growth and survival rate of Redclaw.
\end{abstract}

Keywords: Redclaw, Feeding Frequency, Growth, Survival Rate

\section{PENDAHULUAN}

Lobster air tawar capit merah (C. quadricarinatus) atau "Red Claw" adalah salah satu jenis lobster yang berpotensi untuk dikembangkan sebagai organisme budidaya. Lobster ini masuk dalam anggota Famili Parastacidae yang berasal dari daerah Queensland, Australia. Lobster air tawar dikenal di Indonesia pada tahun 1990 sebagai komoditas hias, namun sekitar 
tahun 2002-2003, status lobster air tawar mulai meningkat menjadi komoditas konsumsi dan mulai dilirik untuk dibudidayakan (Sukmajaya dan Suharjo 2003). Permintaan pasar domestik dan ekspor yang terus meningkat namun produksi terbatas menjadikan komoditas lobster air tawar jenis Red Claw memiliki prospek yang sangat menjanjikan sebagai komoditas budidaya perikanan.

Beberapa keunggulan yang dimiliki Red Claw diantaranya adalah pertumbuhannya yang relatif cepat, mampu dibudidayakan pada kepadatan tinggi, mampu menerima pakan buatan dengan protein yang tidak begitu tinggi serta bentuk morfologinya yang mirip lobster laut sehingga diminati konsumen (Iskandar, 2003). Keunggulan lainnya adalah proses reproduksi singkat karena tidak melewati fase larva seperti udang pada umumnya yang merupakan fase kritis dalam pertumbuhan. Jika dibandingkan dengan jenis lobster air tawar lain, Red Claw tidak memiliki sifat menggali lubang yang dapat menyebabkan kerusakan pada dasar maupun pematang kolam (Lengka, et al., 2013). Beberapa keunggulan ini menjadikan Red Claw sebagai komoditas budidaya andalan yang sedang digalakkan oleh Kementerian Kelautan dan Perikanan (Setiawan, 2006).

Aspek pertumbuhan dan kelulushidupan merupakan aspek terpenting yang harus dikuasai dalam upaya peningkatan produktivitas budidaya Red Claw. Hal utama yang harus diketahui terkait dengan pertumbuhan dan kelulushidupan Red Claw adalah tercukupinya kebutuhan pakan dalam menopang pertumbuhan yang optimal. Kebutuhan pakan dan kemampuan konsumsi pakan Red Claw sangat dipengaruhi oleh manajemen pemberian pakan. Sedangkan manajemen pemberian pakan erat kaitannya dengan frekuensi pakan yang diberikan pada kegiatan budidaya yang dilakukan.

Pengetahuan mengenai frekuensi pemberian pakan optimal pada budidaya Red Claw sangat penting diperhatikan karena berpengaruh terhadap kuantitas pakan yang dikonsumsi, efisiensi pakan, dan kemungkinan terjadinya penurunan kualitas air dalam wadah budidaya. Penurunan kualitas air dalam wadah budidaya akan berpengaruh terhadap kesehatan, pertumbuhan, dan sintasan (Rihardi, et al., 2013).

Kordi (2010) mendefinisikan frekuensi pemberian pakan sebagai kekerapan waktu pemberian pakan dalam sehari. Pada umumnya frekuensi pemberian pakan pada komoditas udang dalam budidaya semi intensif dan intensif antara 4-6 kali sehari. Sedangkan pada sistem ekstensif (tradisional) frekuensi pemberian pakan biasanya dilakukan <4 kali sehari. Frekuensi pemberian pakan yang tepat akan mendukung performa pertumbuhan dan dapat 
mencegah kanibalisme Red Claw yang menjadi salah satu penyebab rendahnya kelulushidupan (Wiyanto dan Hartono, 2007).

Merujuk uraian di atas, penelitian terkait pengaruh frekuensi pemberian pakan terhadap performa pertumbuhan dan kelulushidupan 1Red Claw menarik untuk dilakukan. Penelitian ini bertujuan untuk menyusun suatu variasi frekuensi pemberian pakan yang efektif dan efisien dalam mendukung pertumbuhan dan kelulushidupan optimal Red Claw. Informasi tentang frekuensi pemberian pakan terbaik dalam mendukung pertumbuhan dan kelulushidupan akan sangat bermanfaat bagi pengembangan budidaya Red Claw terutama bagi pelaku budidaya dengan sistem ekstensif.

\section{METODE PENELITIAN}

Penelitian ini dilaksanakan pada bulan Mei hingga Juli 2019 yang berlokasi di Laboratorium Basah Fakultas Pertanian Universitas Islam Indragiri. Peralatan yang digunakan dalam penelitian terdiri dari akuarium berukuran (PxLxT) 60x30x30 cm, pompa sirkulasi air, box filter, aerator, selang, shelter dari pipa paralon ukuran 3/4 inci, daun kelapa, ember/baskom plastic, serok serta alat ukur kualitas air (thermometer, DO meter, pH meter dan ammonia test kit). Bahan yang digunakan terdiri dari lobster air tawar jenis Red Claw $(C$. quadricarinatus) dengan panjang rata-rata $3,15 \pm 0,02 \mathrm{~cm}$ dan berat rata-rata $0,53 \pm 0,11$ gram, serta pellet udang PF-100 berukuran 0,4-0,7 mm dengan kandungan Protein 40\%, lemak 6\%, serat kasar 3\%, abu 15\% dan kadar air 10\% sebagai pakan.

Pelaksanaan penelitian dimulai dengan melakukan pengisian air pada akuarium dengan ketinggian $\pm 10 \mathrm{~cm}$ dari dasar akuarium yang dilanjutkan dengan melakukan instalasi pompa sirkulasi air, box filter, aerator, selang, shelter, dan daun kelapa pada masing-masing akuarium. Setelah proses instalasi selesai dilakukan, seluruh peralatan instalasi diaktifkan dan dibiarkan selama 1 hari sebagai proses resirkulasi air pada akuarium sebagai wadah pemeliharaan. Selanjutnya dilakukan proses aklimatisasi terhadap lobster uji selama 5 hari. Selama proses aklimatisasi lobster uji diberi pakan dua kali sehari secara ad satiasi. Penebaran lobster uji dilakukan pagi hari dengan padat tebar 20 ekor/wadah. Penebaran dilakukan pada pagi hari saat suhu rendah agar lobster uji mudah beradaptasi (Wie, 2007).

Rancangan percobaan yang digunakan pada penelitian ini adalah Rancangan Acak Lengkap (RAL). Percobaan ini terdiri dari 3 variasi frekuensi pemberian pakan yaitu dua kali 
pemberian pakan sehari (A), tiga kali pemberian pakan sehari (B), dan empat kali pemberian pakan sehari (C). Masing-masing perlakuan dilakukan pengulangan sebanyak 3 kali sehingga diperoleh 9 unit percobaan. Proporsi pakan yang diberikan sebesar 3\% dari total biomassa dengan porsi pemberian di bagi sesuai dengan banyaknya frekuensi pada masing-masing perlakuan. Rancangan perlakuan penelitian dijelaskan sebagai berikut:

$\mathrm{A}=$ frekuensi dua kali pemberian pakan dengan interval waktu 12 jam yaitu pada pukul 07.00 dan 19.00 .

$\mathrm{B}=$ frekuensi tiga kali pemberian pakan dengan interval waktu 8 jam yaitu pada pukul 07.00, 15.00 dan 23.00.

$\mathrm{C}=$ frekuensi empat kali pemberian pakan dengan interval waktu 6 jam yaitu pada pukul 07.00; 13.00; 19.00 dan 01.00.

Pemeliharaan lobster uji dilakukan selama 90 hari dengan parameter yang diamati adalah adalah pertambahan bobot, pertambahan panjang dan tingkat kelulushidupan serta beberapa parameter kualitas air yang meliputi suhu, $\mathrm{pH}$ (derajat keasaman), dan DO (oksigen terlarut) dan amonia. Pengamatan pertumbuhan dilakukan setiap 14 hari dengan sampling secara acak terhadap 30\% lobster uji (atau 6 ekor) dari padat tebar per wadah. Pertambahan bobot, panjang dan kelulushidupan lobster uji dihitung menggunakan formulasi Effendie (2002) sebagai berikut:

Pertambahan bobot:

$$
(G)=W t-W o
$$

Keterangan :

$G=$ Pertumbuhan bobot $(\mathrm{g})$

$W t=$ Bobot rata-rata lobster uji pada hari ke-t $(\mathrm{g})$

$W o=$ Bobot rata-rata lobster uji hari ke-0 $(\mathrm{g})$

$$
\text { Pertambahan panjang: } \quad(\boldsymbol{L})=\boldsymbol{L} \boldsymbol{t}-\boldsymbol{L o}
$$

Keterangan:

$L \quad=$ Pertumbuhan panjang $(\mathrm{cm})$

$L t=$ Panjang rata-rata lobster uji pada hari ke-t $(\mathrm{cm})$

$L o=$ Panjang rata-rata lobster uji hari ke-0 $(\mathrm{cm})$.

\section{Tingkat kelulushidupan:$$
\operatorname{SR}(\%)=\frac{N t}{N o} \times 100
$$

Keterangan:

$S R=$ Survival rate/Kelulushidupan $(\%)$

$N t=$ Jumlah lobster uji di akhir pemeliharaan (ekor)

$N o=$ Jumlah lobster uji di awal pemeliharaan (ekor) 
Analisis data menggunakan analisis sidik ragam (Anova) pada taraf signifikansi $5 \%$. Apabila hasil Anova diperoleh pengaruh dari perlakuan terhadap lobster uji maka dilanjutkan dengan uji Beda Nyata Terkecil (BNT).

\section{HASIL DAN PEMBAHASAN}

\section{Pertumbuhan Bobot}

Pertambahan bobot mutlak adalah gambaran perubahan bobot rata-rata individu pada tiap perlakuan dari awal hingga akhir pemeliharaan yang ditentukan berdasarkan selisih bobot akhir dengan bobot awal pemeliharaan. Pertumbuhan dipengaruhi oleh faktor internal dan eksternal. Faktor internal terdiri yang mempengaruhi antara lain keturunan, jenis kelamin, umur, parasit dan penyakit. Sedangkan faktor eksternal yang mempengaruhi pertumbuhan antara lain makanan dan suhu perairan (Effendie, 2002). Pertumbuhan terjadi karena adanya kelebihan energi yang berasal dari pakan setelah dikurangi dengan energi hasil metabolisme dan energi yang terkandung dalam feses (Zonneveld et al. dalam Sari, et al., 2011). Hasil pengamatan terhadap pertumbuhan bobot mutlak rata-rata lobster Red Claw selama penelitian dapat dilihat pada Tabel 1.

Tabel 1. Rata-Rata Bobot Awal, Bobot Akhir Serta Pertambahan Bobot Mutlak Red Claw (C. quadricarinatus) Selama 90 Hari Pengamatan (gram/ekor).

\begin{tabular}{cccc}
\hline Perlakuan & $\begin{array}{c}\text { Bobot Awal } \\
\text { Rata-rata } \pm \text { SD }\end{array}$ & $\begin{array}{c}\text { Bobot Akhir } \\
\text { Rata-rata } \pm \text { SD }\end{array}$ & $\begin{array}{c}\text { Pertambahan Bobot } \\
\text { Rata-rata } \pm \text { SD }\end{array}$ \\
\hline A & $0,54 \pm 0,11$ & $3,14 \pm 0,02$ & $2,60 \pm 0,11^{\text {a) }}$ \\
B & $0,53 \pm 0,12$ & $3,03 \pm 0,05$ & $2,50 \pm 0,13^{\text {a) }}$ \\
C & $0,52 \pm 0,10$ & $2,59 \pm 0,23$ & $2,07 \pm 0,28^{\text {a) }}$ \\
\hline
\end{tabular}

Keterangan: $\mathrm{A}=$ frekuensi 2 kali sehari; $\mathrm{B}=$ frekuensi 3 kali sehari; $\mathrm{C}=$ frekuensi 4 kali sehari; $\pm \mathrm{SD}=$ standar deviasi yang merupakan range dari rata-rata pengulangan masing-masing perlakuan; huruf superskrip ${ }^{\text {a) }}=$ menunjukkan tidak adanya perbedaan yang signifikan berdasarkan uji Anova $(\alpha=0,05)$.

Dari Tabel 1. diketahui pertambahan bobot rata-rata Red Claw selama 90 hari

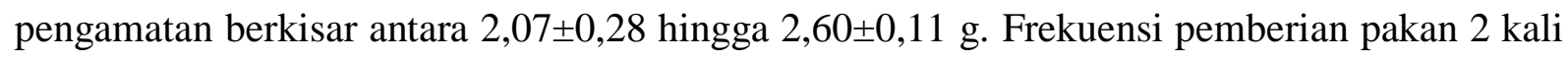
sehari (07.00 dan 19.00) dengan interval waktu pemberian pakan 12 jam cenderung memperlihatkan hasil pertambahan bobot yang lebih baik dibandingkan dengan dua perlakuan

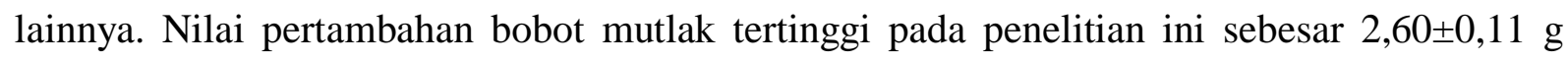
yang lebih tinggi bila dibandingkan dengan penelitian Rihardi, et al. (2013) yang

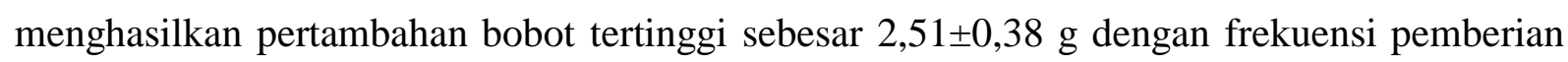


pakan yang sama yaitu dua kali sehari. Perbedaan jenis pakan dan durasi waktu pelaksanaan penelitian diduga menjadi faktor penyebab perbedaan hasil penelitian. Pada penelitian Rihardi, et al. (2013), jenis pakan yang digunakan adalah pellet udang SGH III dengan durasi waktu pemeliharan selama 60 hari, sedangkan pada penelitian ini pakan yang digunakan berupa pellet udang PF-100 dengan durasi waktu pelaksanaan penelitian lebih lama yaitu 90 hari. Tahe, et al. (2017) mendapati bahwa komposisi pakan dan durasi waktu pemeliharaan berpengaruh nyata terhadap pertumbuhan benih udang Vaname pada sistem pentokolan.

Perlakuan dengan frekuensi pemberian pakan 4 kali sehari (Pukul 07.00; 13.00; 19.00 dan 01.00) dengan interval waktu pemberian pakan 6 jam menghasilkan pertumbuhan bobot mutlak yang relatif lebih rendah dari dua perlakuan lainnya. Proporsi jumlah pakan pada frekuansi 4 kali sehari yang lebih sedikit dibandingkan dengan frekuensi pemberian pakan 2 kali dan 3 kali sehari diduga menjadi faktor penyebab relatif rendahnya pertambahan bobot mutlak pada perlakuan ini. Pada pemberian 4 kali sehari, pakan diberikan sebesar $0,75 \%$ dari total biomassa untuk setiap kali pemberian pakan. Durasi waktu pemberian pakan yang tidak sesuai dengan laju pengosongan lambung lobster akan menyebabkan jumlah konsumsi pakan menjadi lebih sedikit akibat ketersediaan pakan yang sedikit pada wadah percobaan (Rihardi, et al., 2013).

Messer dan Rouse (1997) menyatakan bahwa jarak pemberian pakan yang lebih pendek akan menyebabkan jumlah konsumsi pakan akan lebih sedikit. Laju pertumbuhan bobot berhubungan dengan ketepatan antara jumlah pakan yang diberikan dengan kapasitas isi lambung (Sunarno dalam Rihardi, et al., 2013). Pemberian pakan dalam jumlah yang tepat dapat membuat udang tumbuh dan berkembang ke ukuran yang maksimal (Nuhman, 2009). Pakan yang tercerna dengan baik akan menghasilkan pasokan energi yang selanjutnya digunakan untuk maintenance dan aktivitas tubuh, sehingga kelebihan energi dapat digunakan untuk pertumbuhan (Rahmawan, et al., 2014).

Dari hasil analisis sidik ragam (ANOVA) didapatkan bahwa variasi frekuensi pemberian pakan tidak memberikan pengaruh yang signifikan terhadap pertumbuhan bobot mutlak yang ditunjukkan dari nilai $\mathrm{F}$ hitung $(0,983)$ yang lebih kecil dari $\mathrm{F}$ tabel $5 \%(5,14)$. Masing-masing perlakuan penelitian juga memperlihatkan hasil yang tidak berbeda nyata antara satu perlakuan dengan perlakuan lainnya. Proporsi pakan yang relatif kecil yaitu 3\% per hari dari biomassa diduga menjadi faktor penyebab perbedaan pertambahan bobot mutlak antar perlakuan menunjukkan hasil yang tidak signifikan. 


\section{Pertumbuhan Panjang}

Pertumbuhan pada lobster juga ditandai dengan bertambahnya panjang. Pengukuran panjang tubuh lobster dapat digolongkan menjadi dua macam yaitu panjang cephalothorax dan panjang abdomen. Pertumbuhan panjang cephalothorax diukur dalam penelitian ini dengan cara mengukur ujung rostrum hingga akhir carapace (ujung telson). Pertambahan panjang merupakan perubahan panjang rata-rata lobster uji dari awal hingga akhir pemeliharaan berdasarkan selisih panjang akhir dengan panjang awal pemeliharaan (Effendie, 2002). Hasil pengamatan terhadap pertambahan panjang Red Claw dapat dilihat pada Tabel 2.

Tabel 2. Rata-rata Panjang Awal, Panjang Akhir Serta Pertambahan Panjang Mutlak Red Claw (C. quadricarinatus) selama 90 hari pengamatan (cm/ekor).

\begin{tabular}{cccc}
\hline Perlakuan & $\begin{array}{c}\text { Panjang Awal } \\
\text { Rata-rata } \pm \text { SD }\end{array}$ & $\begin{array}{c}\text { Panjang Akhir } \\
\text { Rata-rata } \pm \text { SD }\end{array}$ & $\begin{array}{c}\text { Pertambahan Panjang } \\
\text { Rata-rata } \pm \text { SD }\end{array}$ \\
\hline A & $3,15 \pm 0,01$ & $5,90 \pm 0,09$ & $2,75 \pm 0,10^{\text {a) }}$ \\
B & $3,15 \pm 0,02$ & $5,85 \pm 0,08$ & $2,70 \pm 0,09^{\text {a) }}$ \\
C & $3,15 \pm 0,02$ & $5,75 \pm 0,09$ & $2,61 \pm 0,10^{\text {a) }}$ \\
\hline
\end{tabular}

Keterangan: $\mathrm{A}=$ frekuensi 2 kali sehari; $\mathrm{B}=$ frekuensi 3 kali sehari; $\mathrm{C}=$ frekuensi 4 kali sehari; \pm SD = standar deviasi yang merupakan range dari rata-rata pengulangan masing-masing perlakuan; huruf superskrip ${ }^{\text {a) }}=$ menunjukkan tidak adanya perbedaan yang signifikan berdasarkan uji Anova $(\alpha=0,05)$.

Pengamatan terhadap lobster uji selama 90 hari pemeliharaan didapati pertambahan panjang antara 2,61-2,75 cm. Sedangkan Rihardi, et al. (2013) mendapatkan pertambahan panjang ratarata sebesar 0,95-1,12 cm selama 60 hari pemeliharaan. Kusmini (2010) memperoleh pertambahan panjang sebesar 6,6-7,0 cm selama 3 bulan pemeliharaan. Hal ini menunjukkan bahwa pertambahan panjang rata-rata lobster mengalami peningkatan seiring dengan bertambahnya waktu pemeliharaan.

Analog dengan pertambahan bobot mutlak, pertambahan panjang pada frekuensi pemberian pakan 2 kali sehari memperlihatkan hasil yang lebih baik dibandingkan dengan dua perlakuan lainnya. Hal ini selaras dengan Rihardi, et al. (2013) yang menyatakan bahwa pertambahan panjang pada lobster terkait dengan pertambahan bobot. Pertambahan bobot biasanya ditandai dengan proses molting. Frekuensi pemberian pakan yang optimal akan merangsang lobster cepat molting. Semakin sering molting maka pertumbuhan bobot dan panjang akan meningkat (Setyono, 2006).

Analisis sidik ragam (ANOVA) memperlihatkan bahwa perbedaan variasi frekuensi pemberian pakan tidak berpengaruh signifikan terhadap pertumbuhan panjang dengan nilai $\mathrm{F}$ hitung $(3,66)$ yang lebih kecil dari $\mathrm{F}$ tabel $5 \%(5,14)$. Hasil analisis juga memperlihatkan tidak 
terdapatnya perbedaan yang signifikan dari pertumbuhan panjang antar perlakuan. Analog dengan pertumbuhan bobot mutlak, proporsi pakan yang relatif kecil yaitu 3\% per hari dari biomassa diduga menjadi faktor penyebab hasil antar perlakuan tidak menunjukkan perbedaan yang signifikan.

\section{Tingkat Kelulushidupan (SR)}

Tingkat kelulushidupan adalah perbandingan jumlah lobster yang hidup pada akhir penelitian yang dinyatakan dalam persen (Effendie, 2002). Menurut Watanabe dalam Hutabarat et al. (2015) kelulushidupan dipengaruhi oleh faktor biotik dan abiotik. Faktor biotik terdiri dari umur dan adaptasi, sedangkan faktor abiotik antara lain ketersediaan makanan, padat penebaran dan kualitas air. Hasil pengamatan tingkat kelulushidupan Red Claw pada masing-masing unit percobaan dapat dilihat pada Tabel 3.

Tabel 3. Tingkat Kelulushidupan Red Claw (C. quadricarinatus) Selama 90 Hari Pengamatan $(\%)$

\begin{tabular}{ccccc}
\hline \multirow{2}{*}{ Perlakuan } & \multicolumn{4}{c}{ Kelulushidupan } \\
\cline { 2 - 5 } & $\begin{array}{c}\text { Ulangan 1 } \\
\text { (ekor) }\end{array}$ & $\begin{array}{c}\text { Ulangan 2 } \\
\text { (ekor) }\end{array}$ & $\begin{array}{c}\text { Ulangan 3 } \\
\text { (ekor) }\end{array}$ & $\begin{array}{c}\text { SR } \mathbf{\pm S D} \\
(\boldsymbol{\%})\end{array}$ \\
\hline $\mathrm{A}$ & 16 & 17 & 17 & $83,33 \pm 2,89$ \\
$\mathrm{~B}$ & 16 & 17 & 16 & $81,67 \pm 2,89$ \\
$\mathrm{C}$ & 16 & 15 & 16 & $78,33 \pm 2,89$ \\
\hline
\end{tabular}

Keterangan: $\mathrm{A}=$ frekuensi 2 kali sehari; $\mathrm{B}=$ frekuensi 3 kali sehari; $\mathrm{C}=$ frekuensi 4 kali sehari; $\mathrm{SR}=$ survival rate merupakan persentase tingkat kelulushidupan lobster pada saat akhir penelitian; $\pm \mathrm{SD}=$ standar deviasi yang merupakan range dari rata-rata pengulangan masing-masing perlakuan; huruf superskrip ${ }^{a)}=$ menunjukkan tidak adanya perbedaan yang signifikan berdasarkan uji Anova $(\alpha=0,05)$.

Tingkat kelulushidupan rata-rata Red Claw selama 90 hari pengamatan berkisar antara $78,33 \pm 2,89 \%$ sampai $83,33 \pm 2,89$. Rata-rata kelulushidupan tertinggi didapatkan pada perlakuan frekuensi pemberian pakan 2 kali sehari dengan persentase lobster yang hidup pada akhir penelitian sebesar $83,33 \pm 2,89 \%$, kemudian diikuti dengan perlakuan frekuensi pemberian pakan 3 kali sehari dan 4 kali sehari yang masing-masing memberikan nilai kelulushidupan $81,67 \pm 2,89 \%$ dan $78,33 \pm 2,89 \%$. Kelulushidupan yang paling rendah didapatkan pada perlakuan pemberian pakan 4 kali sehari dengan nilai sebesar 78,33 $\pm 2,89 \%$. Penelitian ini menunjukkan hasil yang lebih rendah dari penelitian Rihardi, et al. (2013) yang memperoleh kisaran tingkat kelulushidupan antara 85-100\% dengan penerapan perbedaan variasi frekuensi pemberian pakan. Sedangkan Prayugo dan Lukito (2007) menyatakan bahwa tingkat kelangsungan hidup benih lobster air tawar berada pada kisaran nilai SR 50\%. 
Kematian yang terjadi pada lobster uji saat pemeliharaan disebabkan oleh sifat kanibalisme dan kurang terpenuhinya kebutuhan akan pakan. Hal ini dicirikan dengan tidak lengkapnya bagian tubuh pada lobster yang mati. Kanibalisme terjadi pada lobster yang berukuran kecil dan lobster yang sedang mengalami pergantian kulit atau molting. Karena pada saat molting lobster akan mengeluarkan aroma yang khas sehingga menarik lobster yang lain dan terjadi pemangsaan. Hastuti (2006) menerangkan bahwa tingkat kelulushidupan lobster sangat dipengaruhi oleh sifat kanibalisme yang tinggi, terutama pada saat ada lobster yang sedang molting. Lobster yang sedang molting biasanya memilih untuk menghindar dari lobster lain, namun dalam skala laboratorium dimana lobster dipelihara dalam akuarium yang terbatas maka lobster yang sedang molting tidak mempunyai pilihan tempat untuk menghindar dari sifat kanibalisme antar sesamanya. Selama proses molting tingkat kematian pada lobster dapat mencapai $30 \%$ yang salah satunya disebabkan oleh kanibalisme (Nainggolan, 2008).

Selain disebabkan oleh sifat kanibalisme, mortalitas pada lobster juga disebabkan karena pakan yang kurang memenuhi kebutuhan sehingga terjadi kompetisi dalam memperoleh makanan. Proporsi pemberian pakan sebesar 5\% dari biomassa pada penelitian Rihardi, et al. (2013) menunjukkan tingkat kelulushidupan yang lebih baik dari kelulushidupan penelititian ini dengan proporsi pemberian pakan 3\% dari biomassa. Kebutuhan akan pakan yang tidak terpenuhi secara optimal akan memicu lobster untuk saling memangsa dan menjadi salah satu faktor penyebab rendahnya tingkat kelulushidupan lobster pada media pemeliharaan. Keterbatasan ruang gerak pada media pemeliharaan dan pengukuran-pengukuran yang dilakukan pada saat penelitian juga dapat memicu terjadinya stress dan berpengaruh pada tingkat kelulushidupan lobster (Jacinto, et al., 2003). Patasik (2005) menyatakan bahwa pengambilan dan perhitungan larva, aklimatisasi atau adaptasi larva serta pemindahan larva ke wadah pemeliharaan juga sangat mempengaruhi tingkat mortalitas Red claw (C. quadricarinatus).

Berdasarkan hasil analisis sidik ragam (ANOVA) diperoleh bahwa masing-masing variasi frekuensi pemberian pakan tidak berpengaruh signifikan terhadap tingkat kelulushidupan yang ditunjukkan dengan nilai $\mathrm{F}$ hitung $(2,33)$ yang lebih kecil dari F tabel 5\% $(5,14)$. Tingkat kelulushidupan juga memperlihatkan kondisi yang tidak berbeda nyata antar perlakuan variasi frekuensi pemberian pakan. Hasil yang sama juga didapati Budiardi et al. 
(2008) dimana Red Claw yang dipelihara selama 42 hari dengan padat tebar 50 ekor $/ \mathrm{m}^{2}$ tidak memberikan pengaruh nyata terhadap kelangsungan hidup dan frekuensi molting.

\section{Kualitas Air}

Parameter kualitas air yang diukur dalam penelitian ini antara lain suhu, $\mathrm{pH}$, oksigen terlarut (DO), dan amonia. Hasil pengukuran parameter kualitas air selama penelitian dapat dilihat pada Tabel 4.

Tabel 4. Kualitas Air Pada Seluruh Wadah Pemeliharaan Selama 90 Hari Pengamatan

\begin{tabular}{ccccc}
\hline \multirow{2}{*}{ Perlakuan } & \multicolumn{5}{c}{ Parameter } \\
\cline { 2 - 5 } & $\begin{array}{c}\text { Suhu } \\
\left({ }^{\mathbf{C}} \mathbf{C}\right)\end{array}$ & $\mathbf{p H}$ & $\begin{array}{c}\text { DO } \\
(\mathbf{m g} / \mathbf{L})\end{array}$ & $\begin{array}{c}\text { Amonia } \\
(\mathbf{m g} / \mathbf{L})\end{array}$ \\
\hline $\mathrm{A}$ & $27,07 \pm 0,23$ & $6,85 \pm 0,26$ & $3,62 \pm 0,35$ & $0,041 \pm 0,04$ \\
$\mathrm{~B}$ & $27,04 \pm 0,25$ & $6,80 \pm 0,28$ & $3,54 \pm 0,37$ & $0,057 \pm 0,02$ \\
$\mathrm{C}$ & $27,38 \pm 0,26$ & $6,72 \pm 0,42$ & $3,47 \pm 0,35$ & $0,098 \pm 0,03$ \\
\hline
\end{tabular}

Keterangan: $\mathrm{A}=$ frekuensi pemberian pakan 2 kali sehari; $\mathrm{B}=$ frekuensi pemberian pakan 3 kali sehari; $\mathrm{C}=$ frekuensi pemberian pakan 4 kali sehari: $\pm \mathrm{SD}=$ standar deviasi yang merupakan range dari rata-rata pengulangan masing-masing perlakuan.

Hasil pengukuran beberapa parameter kualitas air seperti suhu, $\mathrm{pH}, \mathrm{DO}$ dan amonia di masing-masing wadah pemeliharaan masih menunjukkan kisaran nilai optimal dalam mendukung kehidupan lobster Red Claw. Hasil pengukuran terhadap parameter suhu didapati suhu rata-rata pada media pemeliharaan berkisar $27,04 \pm 0,25{ }^{\circ} \mathrm{C}$ sampai $27,38 \pm 0,26{ }^{\circ} \mathrm{C}$, nilai parameter $\mathrm{pH}$ berkisar $6,72 \pm 0,42$ sampai $6,85 \pm 0,26$, DO berkisar $3,47 \pm 0,35 \mathrm{mg} / \mathrm{L}$ sampai

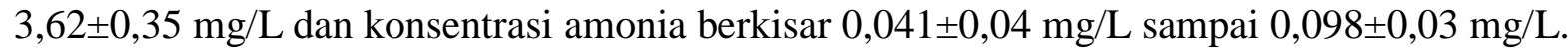

Rouse dalam Kurniasih (2008) menyatakan bahwa lobster jenis Red Claw mengalami pertumbuhan terbaik pada suhu air $24{ }^{\circ} \mathrm{C}$ hingga $29^{\circ} \mathrm{C}$, sedangkan Bardach et al. dalam Kurniasih (2008) melaporkan bahwa pertumbuhan optimum Cherax sp. adalah pada kisaran suhu $21^{\circ} \mathrm{C}$ hingga $29^{\circ} \mathrm{C}$. Hadie dan Hadie dalam Kusmini et al. (2006), proses molting yang diperlukan supaya udang dapat tumbuh memerlukan suhu yang cukup hangat yaitu berkisar $28^{\circ} \mathrm{C}-30^{\circ} \mathrm{C}$

Derajat keasaman sangat menentukan proses kimiawi dalam air (Lesmana dalam Mukti, et al., 2002). Lobster air tawar hidup pada perairan dengan kisaran $\mathrm{pH}$ sedikit basa antara 7,0 hingga 9,0 dan 6,5 hingga 9,0 untuk kegiatan budidaya (Masser dan Rouse, 1997). Sedangkan menurut Bardach et al. dalam Kurniasih (2008) nilai pH ideal bagi pemeliharaan Cherax sp. berada pada kisaran 5,6 hingga 8,2. Pada habitat aslinya lobster air tawar hidup pada $\mathrm{pH}$ berkisar 6,7-7,8 (Suharjo dalam Lengka, et al., 2013). 
Cherax sp. jenis Red Claw dewasa mampu bertahan terhadap kadar oksigen terlarut sangat rendah (sampai $1 \mathrm{mg} / \mathrm{L}$ ), tetapi Red Claw muda lebih rentan (Masser dan Rouse, 1997). Weatly dan Mahon dalam Kurniasih (2008) berpendapat bahwa batas kritis oksigen terlarut untuk Cherax $s p$. adalah $5,2 \mathrm{mg} / \mathrm{L}$ pada suhu $22^{\circ} \mathrm{C}$, sedangkan kandungan di bawah nilai tersebut akan bersifat lethal.

Bachtiar dalam Tumembouw (2011) menyatakan konsentrasi amoniak dalam air akan mempengaruhi pertumbuhan biota budidaya. Jenis Red Claw dewasa menunjukkan toleran terhadap konsentrasi amonia terionisasi sampai $1,0 \mathrm{mg} / \mathrm{L}$ dan nitrit sampai $0,5 \mathrm{mg} / \mathrm{L}$ dalam jangka waktu yang pendek (Anggoro, et al., 2013). sedangkan Rouse dalam Kurniasih (2008) melaporkan bahwa kadar amoniak untuk mendukung kehidupan lobster air tawar tidak boleh lebih dari $0,1 \mathrm{mg} / \mathrm{L}$.

\section{KESIMPULAN}

Berdasarkan hasil penelitian dapat disimpulkan bahwa variasi frekuensi pemberian pakan tidak memiliki pengaruh yang signifikan terhadap performa pertumbuhan bobot mutlak, pertumbuhan panjang dan kelulushidupan Red Claw (C. qudricarinatus). Variasi frekuensi pemberian pakan dua kali sehari cenderung menunjukkan hasil yang lebih baik dibandingkan frekuensi pemberian pakan tiga dan empat kali sehari dengan pertambahan

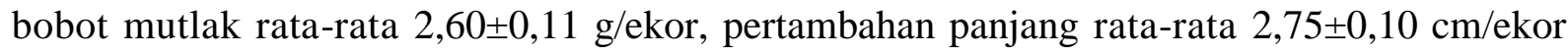
dan tingkat kelulushidupan (SR) rata-rata $83,33 \pm 2,89 \%$. Nilai parameter kualitas air pada seluruh wadah pemeliharaan masih mendukung pertumbuhan dan kelangsungan hidup Red Claw.

\section{UCAPAN TERIMA KASIH}

Penelitian ini didukung oleh hibah Penelitian Dosen Pemula (PDP) Kemenristek-Dikti tahun 2019 yang disalurkan melalui LPPM Universitas Islam Indragiri. Untuk itu tim penulis mengucapkan terima kasih kepada Kemenristek-Dikti, LLDIKTI wilayah X dan LPPM Universitas Islam Indragiri. Ucapan yang sama disampaikan pula kepada pengelola jurnal Simbiosa yang telah berkenan mempublikasikan hasil kegiatan pengabdian ini dan semua pihak yang telah membantu terlaksananya penelitian ini. 


\section{REFERENSI}

Anggoro, S., Subiyanto dan Rahmawati, Y.A. 2013. Domestikasi Lobster Air Tawar (Cherax quadricarinatus) Melalui Optimalisasi Media dan Pakan. Management of Aquatic Resources Journal. Vol. 2(3): 128-137.

Budiardi, T., Irawan, D. Y dan Wahjuningrum, D. 2008. Pertumbuhan dan Kelangsungan Hidup Lobster Capit Merah Cherax quadricarinatus Dipelihara Pada Sistem Resirkulasi Dengan Kepadatan yang Berbeda. Jurnal Akuakultur Indonesia. Vol. 7(2): $109-114$.

Effendie, M. I. 2002. Biologi Perikanan Ed ke-2 (Edisi Revisi). Yayasan Pustaka Nusatama. Yogyakarta.

Hastuti, S.D., 2006. Pengaruh Jenis Pakan yang Berbeda Terhadap Pertumbuhan dan Kelulushidupan Lobster Air Tawar (Cherax quadricarinatus). Jurnal Protein. Vol. 13(1): 95-102.

Hutabarat, G.M., Pinandoyo dan Rachmawati, D. 2015. Performa Pertumbuhan Benih Lobster Air Tawar (Cherax quadricarinatus) Melalui Penambahan Enzim Papain Dalam Pakan Buatan. Journal of Aquaculture Management and Technology. Vol. 4(1): 10-18.

Iskandar, 2003. Budidaya Lobster Air Tawar. Agromedia Pustaka. Jakarta.

Kordi, 2010. Pakan Udang. Akademia. Jakarta.

Kurniasih, T., 2008. Lobster Air Tawar (Parastacidae: Cherax), Aspek Biologi, Habitat, Penyebaran, dan Potensi Pengembangannya. Media Akuakultur. Vol. 3(1): 31-35.

Kusmini, I.I., Hadie, W dan Sianipar, E.P. 2006. Suhu Optimum Untuk Laju Pertumbuhan dan Sintasan Benih Lobster Air Tawar Cherax quadricarinatus. Jurnal Riset Akuakultur. Vol. 1(1): 67-72.

Kusmini, 2010. Keragaan Pertumbuhan Benih Cherax quadricarinatus dari Berbagai Lokasi Untuk Mencapai Ukuran 5-6 Inci. Prosiding Forum Inovasi Teknologi Akuakultur 2010. Balai Riset Perikanan Budidaya Air Tawar. Bogor.

Lengka, K. dan Kolopita, M dan Asma, S. 2013. Teknik Budidaya Lobster (Cherax quadricarinatus) Air Tawar di Balai Budidaya Air Tawar (BBAT) Tatelu. E-Journal Budidaya Perairan. Vol. 1(1): 15-21.

Lukito, A. Dan Prayugo, S., 2007. Panduan Lengkap Lobster Air Tawar. Penebar Swadaya. Jakarta.

Masser, M.P. dan Rouse, D.B., 1997. Australian Red Claw Crayfish. Southern Regional Aquaculture Center (SRAC). Publication No. 244. Southern Regional Aquaculture Center, Stoneville, MS.

Mukti, A.T., Mubarak, A.S dan Ermawan, A., 2009. Pengaruh Penambahan Madu Dalam Pakan Induk Jantan Lobster Air Tawar Red Claw (Cherax quadricarinatus) Terhadap Rasio Jenis Kelamin Larva. Jurnal Ilmiah Perikanan dan Kelautan. Vol. 1(1): 37-42.

Nainggolan. 2008. Uji Efek Ablasi terhadap Pertumbuhan Lobster (Cherax quadricarinatus) pada Wadah yang Terkontrol. Jurnal Ilmiah Satya Negara Indonesia. Vol. 1(2): 2735 . 
Nuhman, N., 2009. Pengaruh Prosentase Pemberian Pakan Terhadap Kelangsungan Hidup dan Laju Pertumbuhan Udang Vannamei (Litopenaeus vannamei). Jurnal Ilmiah Perikanan dan Kelautan. Vol. 1(2): 193-197.

Patasik, S. 2005. Pembenihan Lobster Air Tawar Lokal Papua. Penebar Swadaya. Jakarta. hal. 5-10.

Rahmawan, H., Subandiyono dan Arini E. 2014. Pengaruh Penambahan Ekstrak Pepaya dan Ekstrak Nanas Terhadap Tingkat Pemanfaatan Protein Pakan dan Pertumbuhan Lobster Air Tawar (Cherax quadricarinatus). Journal of Aquaculture Management and Technology. Vol. 3(4): 75-83.

Rihardi, I., Amir, S. dan Abidin, Z. 2013. Pertumbuhan Lobster Air Tawar (Cherax quadricarinatus) pada Pemberian Pakan dengan Frekuensi yang Berbeda. Jurnal Perikanan Unram. Vol. 1(2): 28-36.

Sari, L.K. dan Astusy, S., 2012. Kelangsungan Hidup dan Pertumbuhan Ikan Rainbow Merah (Glossolepis incisus Weber) dan Lobster Air Tawar (Cherax quadricarinatus) Dengan Penebaran yang Berbeda Pada Polikultur Sistem Resirkulasi. Jurnal Perikanan Kelautan. Vol. 3(1): 49-57.

Setiawan, C. 2006. Teknik Pembenihan dan Cara Cepat Pembesaran Lobster Air Tawar. Agromedia Pustaka. Jakarta.

Setyono, D.E.D., 2006. Budidaya Pembesaran Udang Karang (Panulirus spp.). Jurnal Oseana. Vol. 31(4): 39-48.

Sukmajaya, I.Y., Si, M. dan Suharjo, I. 2003. Lobster Air Tawar; Komoditas Perikanan Prospektif. AgroMedia. Jakarta.

Tahe, S., Mangampa, M. dan Suwoyo, H.S. 2017. Pengaruh Lama Waktu Pemeliharaan Terhadap Pertumbuhan dan Sintasan Udang Vaname (Litopenaeus vannamei) Pada Sistem Pentokolan. Prosiding Forum Inovasi Teknologi Akuakultur (pp. 161-168).

Tumembouw, S.S. 2011. Kualitas Air Pada Kolam Lobster Air Tawar (Cherax quadricarinatus) di BBAT Tatelu. Jurnal Perikanan dan Kelautan Tropis. Vol. 7(3): 128-131.

Wie, K.L.C. 2007. Pembenihan Lobster Air Tawar; Meraup Untung dari Lahan Sempit. AgroMedia. Jakarta.

Wiyanto dan Hartono. 2007. Lobster Air Tawar, Pembenihan dan Pembesaran. Penebar Swadaya. Jakarta. 